\title{
ЕТИЧКИ ИЗАЗОВИ У ДОБА АКАДЕМСКОГ КАПИТАЛИЗМА: ЗАДАЦИ КРИТИЧКОГ УНИВЕРЗИТЕТА
}

\section{Сажетак}

Нови јавни менаџмент данас захтева од универзитета да постане предузетничка организација према карактеристикама које поставља капиталистички друштвени поредак. Тако се савремени универзитет може анализирати као установа академског капитализма. То знатно смањује просторе аутономије универзитета, његову критичку, ангажовану функцију јер се универзитет мора односити према тржишту рада (омогућујући лаку запошљивост) и универзитетском тржишту образовних програма на глобалном нивоу не би ли постигао одрживост и ефикасност менаџмента.

Кључне речи: академски капитализам, критички универзитет, академска солидарност, проширени професионализам, предузетнички универзитет, одрживост, универзитетско тржиште, менаџеријализам, запошљивост.

\section{1. Увод}

У савременом свету бројне су одговорности и обавезе универзитета. Ширење образовања и научне мисли тек су полазишта којима су савремене јавне и образовне политике додале бројне задатке: универзитет мора бити кључна платформа за истраживање и производњу знања; мора дати допринос друштвеном и економском развоју радећи на темама које овим питањима могу дати одговоре; да поред образовања критичке интелигенције и научника, образују

Универзитет уметности у Београду, Косанчићев венац 29, Београд 11000

msesic@gmail.com 
и будуће професионалце за тржиште рада какво је данас али и како се предвиђа да ће бити у будућности; да остварује сопствену одрживост дизајнирајући профитне курикулуме а ослобађајући се оних програма за којима тржиште не показује интерес. Сви ови захтеви међусобно су контрадикторни.

Ако се од универзитета очекује да буде окренут научним истраживањима, а истовремено и самоодржив, очито је да ће једно од та два захтева морати тек делимично да буде испуњен. Ако се очекује да наставни програм студенте обучава критичко аналитичком и критичком мишљењу с једне стране, а са друге вештинама које им гарантују запошљивост, такође је очито да ће један од два исхода учења, а најчешће онај који је оријентисан ка критичком мишљењу и индивидуалним потребама сваког студента, бити занемарен. У том смислу, упркос дискурсу који говори о могућностима индивидуације учења, високо нормирани процес наставе не омогућава да се индивидуација, која зависи од специфичног контекста из кога студент долази, истински и спроведе.

Нормирање наставних процеса услед потреба акредитације, глобализованог и због питања о програму за углед (benchmarking), као и развијање универзитета као предузетничког подухвата, део су феномена који се може означити као академски капитализам (Slaughter \& Leslie 1997; Slaughter \& Rhoades 2009).

Овај рад полази од хипотезе да је у савременом друштву упитан јавни интерес у домену високошколског образовања. Савремени универзитет, како његови програми тако и истраживања, под великим су притиском јавних политика, које ограничавају аутономију универзитета и остваривање различитих образовних приступа неопходних различитим геокултурним контекстима. У савременом глобализованом друштву универзитети постају међусобно компетитивни уместо да се развијају према сопственим вредностима и друштвеним потребама њихових средина. Критички универзитет морао би бити проактиван у отварању нових тема и дебата (пре свега о сопственом раду), откривајући нове изазове у глобализованом, али истовремено и веома диверсификованом свету. 


\section{2. Академски капитализам}

Високо образовање у развијеним земљама Запада постало је значајна привредна грана. У Великој Британији она значајно доприноси бруто националном дохотку (1.2\%). Слична је ситуација и у САД у којима универзитети остварују значајну сарадњу са војном, фармацеутском и другим индустријама те тако могу да финансирају врхунске лабораторије у које привлаче врхунске стручњаке из целог света и тако у њима остварују високу концентрацију Нобеловаца и будућих Нобеловаца (од десет првопласираних универзитета по броју Нобеловаца чак седам је из САД са несразмерно највећим бројем Нобеловаца, у просеку са по 80). Аустралија улаже велике напоре преко своје јавне дипломатије да повећа компетитивност својих универзитета на светском тржишту образовања (већ у 2016. години међународно образовање је генерисало рекордних 20,3 милијарди долара да би у 2017. години међународно образовање порасло за $22{ }^{1}{ }^{1}$ ).

У том смислу универзитети у земљама са мањим индустријским и пост-индустријским потенцијалом (банкарство, ИКТ технологије, нанотехнологије итд.), а посебно они на којима се настава одвија на мањинским језицима, тешко се могу упустити у тржишну трку у којој је универзитет схваћен као предузетнички и економски пројекат, а не као стуб друштвеног и културног развоја, темељац националног и културног идентитета. Ипак, универзитети широм света улазе у трку постизања резултата: с једне стране, високо место на Шангајској листи (што значи уступање без накнаде својих научних радова академским концернима Френсис \& Тејлор и Елсевир, који на њима касније остварују велике приходе продајући их управо научним заједницама које су те резултате створиле); с друге стране, универзитети морају постићи сопствену локалну одрживост у ситуацији смањивања јавних средстава која се дају науци и високом школству, што значи да уместо подизања квалитета образовања за врхунски научни рад морају стварати програме који школују вештине тренутно тражене на тржишту; тиме своје најбоље кадрове упућују на одлазак на светске универзитете на којима ће у лабораторијама моћи да добију истраживачке услове којих немају у својим земљама.

$1 \quad$ www.universitiesaustralia.edu.au (13.10.2018.) 
Јасноје да живљењеудруштву стандардизације и нормативизације (у циљу транспарентности и лакше евалуације), што су захтеви Новог јавног менаџмента, захтева квантитативна мерила али искључиво вредновање академских резултата кроз објављивање у индексираним часописима, сигурно редукује културолошки импакт универзитета у срединама у којима је доступност индексираних часописа везана само за најужи круг научне заједнице. Знања која се публикују у овим часописима не могу се репродуковати чак ни на „локалном језику“ јер се то сматра академским ауто-плагијаризмом, а са друге стране и забрањује од стране академских издавача уговорима у којима се аутор одриче свих својих права на текст.

Упркос томе да се уговорима и етичким кодексима настоје да успоставе норме које ће на први поглед бити како морално валидне тако и повољне за научну заједницу, академски капитализам, који вреднује само „бодовни“ успех, како часописима (импакт фактор) тако и појединачним научницима, наметнуо је нове облике „сналажења“. Често је услов објављивања научног текста у часопису реферисање на претходне радове објављене у том часопису, што знатно повећава импакт фактор часописа. наравно да часопис то не може изравно али може неизравно да тражи еуфемизмом: „предност имају радови који продужавају теме које је часопис почео да објављује“. Редакције часописа преко својих чланова који долазе са различитих светских универзитета (који такође имају своје часописе) остварују унакрсне везе и унакрсну цитираност. Овај процес бива награђен повећаним импакт фактором уместо да буде кажњен због стварања непринципијелних, узајамно добитних, веза.

Академско издаваштво у целини у приватном сектору највећи је добитник јавних средстава која се издвајају за науку и кроз бесплатно преузимање научних резултата, често остварених након десетогодишњих пројеката, и кроз наплаћивање продаје ових резултата (а да упркос правилима капиталистичког друштва о праву интелектуалне својине аутори ових научних истраживања ни њихове институције не учествују ни у минималној прерасподели добити).

Колико је академски капитализам захватио универзитетску заједницу показује анализа дискурса којом се акредитују поједини програми те наслови конференција универзитетских и факултетских 
мрежа. Речи попут: предузетништво, одрживост, benchmarking, проширени професионализам, инклузивност почињу да доминирају описима програма, њихових циљева и исхода. Језик модерног менаџмента постао је тако „реалност и у сфери универзитета“ (Protherough \& Pick 2002: 49). Одговорност за запошљавање пренета је са јавних власти (које би биле дужне да развијају тржиште рада и помогну остваривању права на рад) на универзитете и саме грађанедипломце („Сами сте криви ако сте незапослени јер нисте стекли вештине које гарантују запошљивост."). Тако се универзитети стимулишу да процес образовања самоограничавају на наставу вештина и на стицање способности које су тренутно тражене на тржишту рада. Тиме се значајно занемарују обавезе у смислу развоја вредности везаних за уметност и хуманистичке науке које нису директно тражене на тржишту (иако се креативно мишљење високо вреднује у дискурсу нема много примера да се изричито тражи приликом пријема у радни однос). Такође, друштвене и хуманистичке науке које развијају потребу за анализом и промишљањем с једне стране, и критичким мишљењем с друге стране, нису високо вредноване на тржишту рада коме не требају радници који ће успоравати радни процес захтевајући претходне анализе, или бити самоуверени у изражавању свог критичког мишљења према корпоративним лидерима и њиховим одлукама, или према одлукама јавних власти ако су запослени у јавном сектору. Вештине које се траже су „трансверзалне“ вештине: адаптабилност на рад у различитим тимовима, спремност за рад под притиском, лојалност институцији ${ }^{2}$, самопоуздање (глумљено или реално), комуникативност и отвореност (насупрот интровертности која може бити лична карактеристика особе највиших професионалних способности), рад на компјутеру, енглески језик, итд. ${ }^{3}$

2 Она се често своди на послушност, представљање професионализма као испуњавање жеља и наредби власника или менаџера. Позната је максима у РTC-у „вежи коња где ти газда каже“ чиме су професионалци тешили себе да су професионалци тиме што ће испуњавати и задатке које добијају од нестручних или политички мотивисаних продуцената и уредника.

3 У том смислу сет ових вештина јесте парадигма вештина које се траже за рад у кол центрима у Србији али и широм света, који за изузетно баналне послове по правилу запошљавају универзитетски образоване дипломце са мастерима друштвенохуманистичких наука. 
Комерцијални притисци на универзитет, иако постављени јавним образовним политикама, подржани су и захтевима крупног капитала који жели да јефтино дође до знања што најлакше обезбеђује управо универзитет. Тако се универзитет, под притиском менаџерске културе (Protherough \& Pick, 2002), окреће од истраживања и продукције знања (што су домени у јавном интересу) према настави вештина. Отварају се програми који се правдају интересом тржишта (пре свега за професије неопходне приватном капиталу иако се њихово школовање бар делимично финансира јавним новцем). Стога не чуди порука: Do Nothing! (2005) групе кустоса и уметника у Црној Гори упућеној црногорској државној управи (иако је била упућена пре свега „инвестиционим пројектима“), јер је некада боље без јавних политика но са лошим јавним политикама које угрожавају будућност и културну одрживост ${ }^{4}$ једне средине.

Тако се и од универзитета очекује да буде „ефикасан“ и „продуктиван“ јер то су две основне категорије менаџерског приступа било ком домену деловања. Болоњска конвенција је и доживела у Србији највећи отпор управо због нормиране „ефикасности студирања“, што је подразумевало да се универзитет мора завршити у одређеном року иначе се губи право на школовање (тиме није одговорност пребачена само на студенте већ пре свега на оне професоре и предмете који су представљали тзв. уска грла и који су заустављали у студирању велики број студената). Упркос томе што је та одредба по себи била позитивна јер је утицала на промене наставних програма (да они постану савладиви и за просечног студента), она је имала и негативне последице да се један програм вреднује пре свега по својој продуктивности (колико дипломаца „избацује“ на тржиште), што је утицало на смањивање квалитета наставе. Отпор продуктивности као савременој вредности јавног сектора није исказивана у универзитетским дебатама (јер се ипак доживљавала и као борба против некадашњег ,јавашлука“), али је овај отпор јасно исказиван у уметности уз „похвалу лењости“ која омогућава стваралаштво (Стилиновић 1993).

4 Појам одрживости се нажалост најчешће примењује на економску одрживост установе или пројекта а да се при том занемарује њихова културна одрживост (Dessein et al. 2015) што подразумева одржање њихове мисије и циљева. Установа под комерцијалним захетевима мења своју суштину и економски опстаје али њени садржаји више нису у јавном интересу. Најбољи пример представља „одрживост“ некадашњих локалних јавних радио и ТВ станица као и радио ТВ станица цивилног друштва које су данас пуки забављачи (од радија Б92 до Плеј радија као парадигме ове промене). 
Развој универзитета све више се заснива на тзв. прагматичним одлукама. Универзитетске управе бирају од предложених програма оне који ће најбоље изгледати на тржишту рада, који су прилагођени запошљивости, а са друге стране подстичу пре свега примењена истраживања, најчешће она за која се јавно исказује интерес владе (нпр. дигитализација итд.). Нови јавни менаџмент у високом образовању уводи нормативе и стандарде евалуације који ограничавају просторе аутономије како катедри тако и сваког појединог универзитета, стога што програми треба да буду компарабилни, да имајy benchmark, а у многим случајевима и да су развијени према интересима великих корпорација. Овај интерес је у свету усмерен ка универзитету а у Србији је нарочито видљив у секундарном и струковном високом образовању, тзв. дуалном образовању које се све више Србији намеће јасно указујући да индустрија која се у њој развија није нова модерна индустрија која захтева истраживања већ стандардна која захтева нискообучене раднике.

Чак и универзитети и факултети уметности, који су све до скора стављали фокус на развој уметничких истраживања, на тзв. креативне праксе, истраживања заснована на социјално ангажованим уметничким праксама (Miles 2005) данас све већу пажњу поклањају свету рада и запошљивости својих студената подстичући такође услове за њихову студентску продуктивност и ефикасност. Тако је ЕЛИА (Европска лига института уметности / European League of Institutes of Arts), која умрежава преко 500 европских уметничких школа, у 2015. добила грант Креативне Европе за трогодишњи међународни пројекат NE@XT ACCELERATOR - Making a Living From the Arts у коме је учествовало 25 партнера из 15 земаља. Смисао пројекта је био подстицај уметничким школама да већу пажњу обрате на свет рада који је у сталној промени и да преузму на себе обавезу да брину о предавању и стицању трансверзалних вештина којима ће студенти уметности моћи да развијају своје каријере на тржишту рада (Danhash \& Lehikoinen 2018; Danhash 2018).

Није чудо да се проучавањем тржишта рада и његових доминантних форми референтних за уметност и уметничко стваралаштво дошло до креативних индустрија и креативних хабова као кључних потенцијала за укључивање тек дипломираних младих уметника. Ако је циљ пројекта и именован као Зарађивање за живот 
бављењем уметношћу онда не чуди да је свет креативних индустрија, оглашавања, дизајна и моде као и свет забаве и клабинга управо онај који то омогућава. То није нова појава: одувек су уметници који су желели да живе од креативног рада одлазили у свет забаве и моде, од Холивуда и париских кабареа (плакати Тулуз-Лотрека) до Вога и других модних часописа (Милена Павловић Барили). Није било спорно да уметник који има своје професионалне уметничке вештине (цртача, вајара који је и мајстор за одливке, итд.) лако може да нађе своје место на ширем тржишту а да за њега не мора да буде специјално школован, већ да школовање буде фокусирано на развој његових креативних способности и професионалних извођачких вештина. Данас је потребно доказати већ у нацрту програма да ће универзитет тј. висока уметничка школа омогућити студенту да научи шта је оглас, плакат, да стекне комуникационе вештине (убеђивање, преговарање), да научи писање пројеката, маркетинг, менаџмент и све друго што је до сада била обавеза менаџера, продуцената, галериста - подједнако и установа у јавном и оних у приватном сектору. Данас се саветује уметнику да се ослања само на себе и да стога мора да научи и маркетинг микс (а нарочито како себи да одреди цену) и деловање на међународном тржишту и деловање у локалној заједници (што може да омогући додатне приходе за партиципативне и инклузивне уметничке програме). Све ово по себи не би морало да буде лоше, јер добро је имати уметника који зна потребе и процесе који се дешавају у сфери културе, како у свом друштву тако и у Европи и у свету. Међутим, то није добро ако се тиме аболира високо финансиран јавни сектор у култури од своје одговорности да пружа уметницима и уметничком стваралаштву како подршку тако и услове за рад. Галерије културних центара тако јесу места излагања али оне морају бити и места продукције - дакле морају преузети одговорност и за финансирање уметничке продукције тако што ће учествовати у конкурсима свих нивоа власти у име уметника и уметничких колектива.

Нека удружења уметника у Србији већ преузимају ову одговорност на себе (Удружење драмских уметника), али је мали број јавних установа које би конкурисале за уметничке пројекте и у име уметника који нису у њима стално запослени. Недовољност јавних субвенција чини њих равноправним „конкурентом“ на конкурсима јавних вла- 
сти, што они свакако нису, па онда на први поглед има смисла задатак уметничких школа да обучава уметнике за наступање на тржишту рада. Међутим, већ анализа коју је спровела ЕЛИА (Heinsius 2018) показује да највећи број креативних хабова представља заједнички, дељени пословни простор за оне уметничке организације које се могу директно препознати на тржишту (дизајн, архитектура, звук, светло итд.) те се и консултантске и друге услуге (образовање, рачуноводство, правни савети) усмеравају ка њима а не ка уметницима који настављају да делују у традиционалним пољима уметности (извођачке и визуелне уметности).

Цео дискурс савремених културних политика који је усмерен на креативне индустрије, креативне градове, предузетништво у култури и менаџеријализам занемарује поље уметничког стваралаштва као таквог па теме попут изградње атељеа за уметнике, лабораторија за нове медије у јавном власништву и друге инфраструктуре која би омогућила деловање уметника кроз сопствено стваралаштво које нема примењену компоненту остају сасвим по страни. Установе културе својим статутима и годишњим уговорима нису стимулисане да сарађују са уметничким и културним организацијама цивилног друштва већ се према њима односе као према клијентима којима наплаћују, по истим ценама, изнајмљивање свог простора и опреме.

Универзитети који предају хуманистичке науке и уметност нису препознати као важни актери савременог доба у друштвима која убзано мењају свој демографски састав, ставове, вредности и политичке оријентације. Политички популизам који утискује свој комуникациони стил у јавне праксе учинио је да се они маргинализују у јавној сфери као и цео систем културе коме је такође наметнут мешовити модел пословања. Тај модел подразумева да јавне власти покривају из буџета само основне трошкове (део плата и материјалних трошкова) а да се цео програмски део буџета мора тражити кроз додатни фандрејзинг (уколико не успе да се оствари, установа неће бити кажњена 5 ).

Колико је велика важност хуманистичких наука у културним системима европских земаља данас говори и чињеница да је у многима

5 Добар пример је Студентски културни центар који готово да нема програма који се не могу самофинансирати. Тако се пласирају углавном концерти и пројекције или разговори који се заснивају на про боно контрибуцији учесника. Упркос томе, Министарство просвете као надлежни орган власти никад не доводи у питање квалитет рада ове установе. 
од њих дошло до „ревизије“ прошлости у којима наука практично не учествује. Стога би било од великог значаја да се на том пољу сретну научна и уметничка истраживања, дакле универзитети хуманистичких дисциплина са уметничким факултетима а да се њихови резултати чине јавним користећи установе јавног сектора као платформе за презентацију широј јавности. И прошле и садашње друштвене норме, етичке контроверзе, културне вредности, људска права али такође и друштвена правда морају да буду део тих дебата, заједно са другим бројним питањима везаним за последице миграција, популизма и других глобалних изазова.

Данас је кључно питање како постићи да универзитет опстане као делатан актер јавне сфере. Аутономија универзитета чини се да је остварена али се суштински све више сужава јер универзитети нуде програме који су „актуелни“, друштвено пожељни са становишта јавних политика, без обзира да ли се односе на кључна, тренутно горећа друштвена и културна питања. И националне власти и Европска унија расписују конкурсе за научноистраживачке пројекте у којима се јасно наводе приоритети и прецизне програмске линије уз кључне речи које се мењају из године у годину. Без обзира шта о томе мислили, да би добили грент за пројекат, научници морају користити актуелни дискурс (партиципативност, ко-креација, креативне индустрије, препоруке за јавне политике итд.).

Шта су предуслови да аутономија универзитета опстане у савременом популистичком тренутку који поништава и омаловажава знање и стручност? ${ }^{6}$ А како спречити да опстану програми који нису профитабилни (класичне науке и језици, филозофија, уметности...)? И како учинити да у програмима не претежу трансверзалне над професионалним вештинама, иако није спорно да многи универзитетски програми треба да захтевају и њих, али и много више професионалних вештина (уреднички рад у издаваштву на филолошким факултетима; постављање изложбе и њено осветљавање за студенте историје

6 Тако на пример одборница суботичке градске скупштине, Јосипа Иванковић, бранећи именовање агронома за директора биоскопа каже да свако може управљати биоскопом без обзира на стручну спрему уз одговарајућу политичку подршку. „Њоме може да се бави и занатлија и доктор наука. Директор установе треба да буде менаџер, а изабрана је пре свега економиста." https://www.subotica.com/vesti/izbordirektorke-lifke-izazvao-zustru-polemiku-id28653.html (13.10.2018.) 
уметности, антропологије, историје...). Међутим, још је важније обезбедити и осигурати аутономан простор у оквиру наставних програма и за професоре и за студенте да слободно предузимају ризичне критичке приступе посебно у друштвеним и хуманистичким наукама.

Питања дисонантног наслеђа, табу теме везане за одређене историјске периоде и личности, геополитичке процесе итд. често се прескачу у формулацијама садржаја наставних програма да би он био што лакше акредитован а и да не дође до конфронтација. Стога се дешава парадокс да се о одређеним појавама (владавина краља Александра; социјалистички период; Косово...) више дебатује изван но у научној сфери. Академски капитализам у време популистичких политика не подстиче истраживања која су контроверзна, око којих нема научног консензуса и која могу наићи на политичку осуду владајућег естаблишмента или моћних културних кругова.

\section{3. Образовање као инвестиција}

Академски капитализам захтева да се образовање схвата као инвестиција у будућу каријеру па самим тим и у будуће приходе. Стога се подразумева да се високо образовање мора да плаћа иако неке европске државе (Финска, Француска) и даље подржавају бесплатно образовање и на овом нивоу.

Ако је високо образовање само инвестиција са друштвене тачке гледишта онда се млади људи подстичу да посматрају свој будући програм са становишта исплативости инвестиције па ће улагати искључиво у оне студијске програме, које често не прати озбиљна истраживачка, научна основа (ИКТ, менаџмент, безбедност, финансије, маркетинг и ПР, итд.) који могу да гарантују не само брзу запошљивост већ и високе приходе након дипломирања или брз одлазак у свет у којем се ти високи приходи могу стећи. Нису више само МИТ или Харвард они који се рекламирају са паролом да њихови дипломци већ у првој години могу да рачунају са 100 хиљада долара годишњег прихода већ и факултети у Србији наводе сличне, наравно не тако високе, могуће резултате. ${ }^{7}$

7 „Широм отвара врата средњошколцима и нуди улазак у свет рада...“ (Мегатренд). „Отвара сва врата за бављење жељеном професијом у будућности“ (ФАМ Сремски Карловци) 
Поред ових програма и неки програми хуманистичких и уметничких дисциплина који су везани за теоријска промишљања али своје пословно утемељење налазе у креативним индустријама (дизајн, кустоске праксе) или високо тржишно оријентисане уметности (Дејмијан Херст ${ }^{8}$ као парадигма) могу имати значајније, иако не бројчано јако високо тржишно интересовање.

Академски департмани друштвених наука $и$ хуманистике као и уметнички одсеци морали би бити кључне платформе за преиспитивање друштвених норми правила, за развој креативности и иновација како унутар саме академске сфере тако и у широј јавности. Користећи јавни медијски и културни систем они постају платформе за подизање јавне дебате и слободног друштвеног дијалога о контроверзним питањима друштвенополитичког развоја која могу провоцирати бројне етичке дилеме. Одговорност савременог универзитета тим је већа јер је он парадигма јавне установе у неспорном јавном интересу. Још од 19. века он је један од стубова изградње нације, док је у модерним временима његово космополитско утемељење омогућило да се друштвима отварају знатно шири критички и аналитички хоризонти. Универзитет, концептуализован као јавна установа, био је отворен не само за приофесоре и студенте већ и за читаву јавност, дакле за све оне који учествују у формирању јавног мњења дискутујући о важним или занемареним питањима сопственог друштва али и човечанства у целини.

Током историје када би се универзитети сувише издвојили од јавности или пак од јавног утицаја, настајале су сличне јавне установе чији је разлог постојања био управо јавно деловање. Од Француског колеџа (College de France) до Коларчевог народног универзитета у Бе-

8 Управо стога је изложба Дејмијана Херста, као симбола комерцијализације уметности, одржана у Музеју савремене уметности у Новом Саду (2.9 - 14.10.2016.), доживела приликом отварања и демонстрације које су предводили савремени српски визуелни уметници (Živko Grozdanić). «lako umetnici i aktivisti nisu ničim kršili javni red, ispred muzeja su predati policiji koja ih je legitimisala i sprečila da se vrate u muzej», navodi se u saopštenju. Za jednu od najvećih izložbi ministarstvo kulture i pokrajina izdvojili su ukupno 1,1 milion dinara, što je oko trećine iznosa koji se godišnje izdvaja za sve programske aktivnosti Muzeja savremene umetnosti Vojvodine. Finansiranje takve izložbe u trenutku kada su odvajanja države za kulturnu produkciju nikad manja, izazvalo je revolt dela umetničke javnosti. http://rs.n1info.com/a190107/Vesti/Kultura/Izlozba-Novareligija.html (13.10.2018.) 
ограду ове институције су формирале независне катедре чији је циљ био доступност знања. Савремени универзитет се током шездесетих година двадесетог века отворио за јавност али је нажалост у 21. веку због процеса секуритизације, тј. јачања безбедности на кампусима, дошло до поновне изолације универзитетске јавности. Различити програми попут ТЕД и ТЕДх предавања на Јутјубу као и виртуелне учионице Харварда, Лондонске школе економије и других универзитета чине део знања стеченог истраживањем доступним широј јавности чиме се делимично испуњава функција јавне одговорности универзитета.

Посебно је важно што се управо кроз ове виртуелне програме више но кроз програме који се морају економски исплатити, универзитети окрећу ширењу знања у доменима културе људских права и друштвене правде. Тако се и кроз истраживања и кроз јавну дебату универзитети окрећу против „моралне слепоће утилитарних наука“ (Bauman \& Donskis, 2013). Управо стога је важно да се очувају друштвено-хуманистичке науке и уметничке праксе на универзитетима, јер су оне те које постављају кључна, често непријатна, друштвена питања, насупрот доминантних комерцијалних академских токова и дневнополитичких интереса владајућих структура.

Универзитет би морао да делује као платформа за испитивање вредности и ограничења неолибералног и глобализованог друштва на неколико нивоа:

- $\quad$ кроз научноистраживачки рад, научни дискурс и полемику (научна сфера)

- $\quad$ кроз јавне активности - конференције, фестивале, догађаје (јавна културна сфера)

- $\quad$ кроз популаризаторске праксе (медијска и културна сфера)

- кроз утицај на јавне политике (партиципација у јавним дебатама приликом доношења закона, стратешких планова и других докумената од значаја)

- $\quad$ кроз сопствене пројектне праксе намењене студентима, итд.

Иновативне универзитетске праксе које очувавају аутономију универзитета јер су инспирисане сопственим потребама, а не наметнутим захтевима од стране јавних власти било ког нивоа, од изузетне су важности у овом тренутку. Иако је универзитет дисциплинарно структурисан иновације су најчешће у трансдисциплинарним ис- 
траживачким пројектима, програмима мастер и докторских студија те кратким летњим курсевима и другим ад хок пројектима. На тим местима универзитети најчешће делују као платформе критичког мишљења и делања на којима универзитетски професори преузимају улоге критичких јавних интелектуалаца спремних да доприносе друштву стварањем нових агенди деловања.

Веома је тешко обезбедити одрживост таквих пројеката што показујеједан однајинтересантнијихи најиновативнијихмеђународних пројеката: Мастер међународних истраживања извођачких уметности (универзитети у Ворику, Хелсинкију, Амстердаму и Универзитет уметности у Београду) који се угасио услед „недовољне профитабилности“ иако је био самоодржив. Универзитетским властима у Амстердаму и Ворику није била довољна само одрживост програма већ су захтевали и високу профитабилност која се у домену уметности не може остварити на начин на који је то могуће у неким другим дисциплинама (Bala et al. 2017).

Критички универзитет мора да буде способан да врши истраживања и изван своје уобичајене дисциплинарне сфере и да тако уводи бритке, иновативне идеје уакадемски дискурсподржавајући истовремено критичку јавну дебату. Тако се долази до нове могућности да се ремиксује знање (Dragićević Šešić \& Jestrović 2017) створено од стране различитих друштвених актера, како у јавном сектору, тако у цивилном друштву ${ }^{9}$. Ремикс култура данашњег времена (Lessig 2004) захтева трансдисциплинарност универзитета с једне стране, а истовремено омогућава и доступност знања не само студентима већ и грађанству у најширем смислу (Riffkin 2000). Тиме се демократизује универзитет и јача његова функција у заједници како на локалном тако и на глобалном плану.

Дајући простор студентима за самостално пројектно и активистичко деловање, универзитет се још више отвара ка јавности, посебно оној која се управо генерацијски конституише у новим алтернативним просторима. Узимајући за аналитичке примере пројекте: студената прве године Менаџмента и продукције у позоришту, радију и култури на Факултету драмских уметности у Београду, као и студената мастер студија УНЕСКО катедре за културну политику и менаџмент

9 Нажалост, сектори и одељења за истраживања и развој у приватном сектору у Србији одавно више не постоје. 
Универзитета уметности у Београду (генерација 2017-18) показујем до које мере они излазе изван оквира наставних програма у поље трансдисциплинарности и друштвеног активизма.

Четири пројекта студената прве године, потпуно самостално концептуализована (уз сарадњу са докторандкињом Татјаном Николић), покрила сучетири значајна контроверзна друштвена питања: питање културе сећања породице и друштвене заједнице на Први светски рат; транзиционо уништавање јавних објеката културе (биоскоп Вождовац); неопходност успостављања прекинутих југословенских културних и академских веза (сарадња загребачких и београдских уметничких школа); и могућност реализације интерактивних уметничких пројеката коришћењем нових технологија у сарадњи уметника звука и публике. Сви ови пројекти реализовани су у новим, алтернативним просторима (нпр. Квака 22, Клуб на Дорћолу) или на улицама и трговима разоткривајући и њихову приватизацију (трг испред некадашњег биоскопа Вождовац за који је МУП дао дозволу а приватно обезбеђење новог власника биоскопске зграде онемогућило јавну акцију).

Четири пројекта студената УНЕСКО катедре везани су били за Нови Сад - културну престоницу Европе 2021. године, третирајући феномен друштвене периферије на различитим нивоима (задата тема). Бирајући затвор у Клиси као оквир за испитивање могућности коришћења примењеног позоришта како у сврхе рехабилитације затвореника тако и у сврхе реинтеграције овог изолованог комплекса унутар једне друштвене заједнице, студенти су пред себе поставили задатак какав наставни програми глуме, режије или било које друге уметности себи никада нису поставили сматрајући га претешким изазовом. Друга група студената определила се за пројекат повезивања периферијских малих градова по ободу Фрушке Горе користећи културни туризам као платформу за интеграцију наслеђа и савременог стваралаштва које званични курикулуми ретко интегришу. Трећи пројекат заснивао се на методу усмене историје као методу грађења нове колективне културе сећања јер је то метод који није полазио од историјских личности и сведока историјских збивања већ од маргинализованих припадника локалних заједница чији се глас до сада није чуо. Четврти пројекат избацио је у први план сеоске и приградске ос- 
новне школе као могућа културна средишта друштвених заједница без икаквих локалних јавних културних и друштвених установа.

\section{4. Закључак}

Универзитети широм света налазе се на прекретници: да ли ће остати верни својим принципима или ће своје програме прилагођавати захтевима тржишта и јавних политика? Посебно су то тешке дилеме за факултете уметности и друштвено-хуманистичких наука који се не препознају у модерном глобализованом свету корпоративног капитализма. Упркос вербалним исказима којима нове универзитетске управе подржавају трансдисциплинарност и искораке ка иновативним праксама, реалност показује да гро средстава одлази на оне пројекте и програме који су већ високо профитабилни или указују да то могу постати.

Стога је изузетно важно да се универзитетска јавност самоорганизује и да у међусобној сарадњи остварује трансдисциплинарне и прекограничне програме повезујући иновативно креативно образовање (уметност), критичко мишљење и деловање (друштвенохуманистичке науке) и нове технологије (потенцијално профитабилне праксе које се могу битно развити уз сарадњу са претходне две). „Кроз јачање свих друштвених актера и улазећи у јавну сферу на различите начине (перформансе, јавне акције, радионице, конференције и семинаре) универзитет доприноси уношењу критичких тема на политичку и друштвену агенду, подржавајући демократске процедуре и институције и јачајући компетенције оних који учествују у јавној власти“ (Dragićević Šešić \& Jestrović 2017: 71). Трансдисциплинарни приступи и методе, укључујући practice as research (на пракси засновано уметничко истраживање), примењени на бројне феномене стварности: од капитализма и његових ефеката, преко урбанизма (право на град), јавни менаџмент (преиспитивање јавно-приватног партнерства као облика деловања), комодификацију, компетитивност, национализам, културу сећања итд. остварили су значајне искораке у концептуалним елаборацијама ових феномена до којих дисциплинарне науке нису дошле. 
Стога овај рад представља не само position paper, већ пледоаје за самоорганизацију и повезивање научника и уметника који делају на универзитетима Србије, Европе и света да кроз интер и трансдисциплинарне пројекте, од научноистраживачких до едукативних, бране своју аутономију, а истовремено успостављају платформе за боље разумевање и критички однос према друштвеној стварности те за креирање нових форми и облика деловања важних за свеукупни и одрживи развој друштвене заједнице.

\section{Извори и литература}

Bala, Sruti et al. (eds.). International Performance Research Pedagogies. Palgrave Macmillan, 2017. Štampano.

Bauman, Zygmunt \& Donskis Leonidas. Moral Blindness: The Loss of Sensitivity in Liquid Modernity. Polity, 2013. Štampano.

Danhash, Nadia \& Lehikoinen, Kai. Career in the arts: visions for the future, Amsterdam: ELIA, 2018. Štampano.

Danhash, Nadia. "The World of Work". Danhash, Nadia \& Lehikoinen, Kai. Career in the arts: visions for the future. Amsterdam: ELIA, 2018. Štampano.

Dessein, Joost et al. Culture in, for and as sustainable development. Jyvaskyla: University of Jyvaskyla, 2015. Štampano.

Dragićević Šešić, Milena \& Jestrović, Silvija. "The University as a Public and Autonomous Sphere: Between Enlightenment Ideas and Market Demands". Bala, Sruti et al. (eds.). International Performance Research Pedagogies. Palgrave Macmillan, 2017. Štampano.

Heinsius, Joost. "From Education to Professional Practice: Are the Creative Hubs the Answer?". Danhash, Nadia \& Lehikoinen, Kai. Career in the arts: visions for the future. Amsterdam: ELIA, 2018. Štampano.

Lessig, Lawrence. 'Free(ing) Culture for Remix' Utah L. Rev., 2004: 961. https://heinonline. $\mathrm{org} / \mathrm{HOL} /$ LandingPage?handle=hein.journals/utah/r2004\&div=43\&id=\&page= (13.10.2018.). Veb.

Miles, Malcolm. (eds.). New Practices - New Pedagogies. A Reader. Routledge, 2005. Štampano.

Protherough, Robert \& Pick, John. Managing Britannia. London: Edgeways, 2002. Štampano.

Riffkin, Jeremy. The Age of Access, The New Culture of Hypercapitalism, Where All of Life Is a Paid-For Experience. Tarcher, New York: Putnam, 2000: 114-33. Štampano.

Slaughter, Sheila \& Leslie, Larry L. Academic Capitalism: Politics, Policies and the Entrepreneurial University. Baltimore: Johns Hopkins University Press, 1997. Štampano.

Slaughter S. \& Rhoades G. Academic Capitalism and the New Economy. Johns Hopkins University Press, 2009. Štampano. 
Stilinović, Mladen. In Praise of Laziness. http://monumenttotransformation.org/atlasof-transformation/html/l/laziness/in-praise-of-laziness-mladen-stilinovic.html (13.10.2018.). Veb.

\section{Milena Dragićević Šešić, PhD}

\section{ETHICAL CHALLENGES IN THE ERA OF ACADEMIC CAPITALISM: MISSION OF CRITICALLY ENGAGED UNIVERSITY}

\section{Summary}

Today New Public Management demands from universities to become entrepreneurial organizations according to criteria that are formulated by capitalism as global social formation. Thus, contemporary university might be analyzed as the institution of academic capitalism. That limits spaces of university autonomy as well as its critically engaged functions as its main tasks are to educate new generations of graduates according to employability defined by labor market. At the same time university has to become competitive on the global market of university programs and services thus achieving its own sustainability, efficiency of management but also profitability that would endorse investment in new hubs and laboratories and research that is demanded by corporations or political authorities.

That forces universities around the world to balance in-between their original principles and new market demands. These dilemmas are especially difficult for schools in arts and humanities that have hard time to define their new missions in the new world of corporate capitalism. In spite of discourses of new university managements that endorse transdisciplinarity and innovation, the research shows that most of resources are given to those projects and programs that are already highly profitable or have that potential. It is therefore very important for the academic community to self-organize and find ways in collaboration and academic solidarity to create transdisciplinary and transborder programs connecting innovative creative education (arts), critical thinking and acting (social sciences and humanities), and new technologies (potentially profitable practices that could be developed with collaboration of previous two, not necessarily only in the domain of creative industries).

Through two case studies (both from the University of Arts in Belgrade: from Departments of Management and Production in Theatre, Radio and Culture; and UNESCO Chair in Cultural Policy and Management - master program) the author explained to what extent students can be empowered to contribute to the development 


\section{Култура универзитета и филологија}

of socially responsible university undertaking projects in public interest. „Through the empowerment of different social agents who enter the public spheres in different ways (via performances, public actions, workshops, conferences and seminars), universities contribute to putting critical issues on the political agenda endorsing democratic procedures and institutions as well as raising the level of competence in public governance" (Dragićević Šešić \& Jestrović 2017: 71). Transdisciplinary approaches and methods, including practice as research, applied in numerous research: from capitalism and its social effects, through urbanism (right to the city), public management (reconsideration of public-private partnership), commodification, competitivity, nationalism, culture and politics aof memory, etc. have achieved important results in their conceptual elaborations beyond usual explanations of disciplinary research. Therefore, this text is more than just a position paper, it is a plaidoyer for self-organization and connections of researchers and artists that are active in academic and cultural realms. Through interdisciplinary and transdisciplinary projects both in research and education they should defend university's autonomy but succeed in creating new platforms for better understanding and critical relation towards social realities and new organizational and operational models of acting important for sustainable (cultural and economic) development of their community and the global world.

Key words: academic capitalism, critical university, academic solidarity, extended professionalism, entrepreneurial university, sustainability, university market, managerialism, employability 